\title{
RANCANG BANGUN APLIKASI PEMBELAJARAN BAHASA INGGRIS UNTUK ANAK-ANAK MENGGUNAKAN TEKNOLOGI KINECT
}

\author{
Azkia Nury Farizah ${ }^{1}$, Mungki Astiningrum² \\ ${ }^{1}$ Teknik Informatika, Teknologi Informasi, Politeknik Negeri Malang \\ ${ }^{1}$ azkianuryfarizah@gmail.com, ${ }^{2}$ mungki_astiningrum@polinema.ac.id
}

\begin{abstract}
Abstrak
Bahasa Inggris merupakan Bahasa Internasional yang harus dikenalkan sejak usia dini pada anak-anak. Pengenalan Bahasa Inggris pada anak-anak harus dilakukan dengan cara yang menyenangkan, salah satunya adalah dengan menggunakan aplikasi pembelajaran yang dilengkapi dengan permainan. Anak-anak pada umumnya senang bermain dan bergerak, karena pada usia anak-anak, kemampuan kognitif dan motorik berkembang secara bersamaan. Tujuan dari penelitian ini adalah membuat Aplikasi Pembelajaran Bahasa Inggris yang melibatkan aktivitas motorik. Aplikasi ini dijalankan dengan menggunakan sensor Kinect dan menggunakan Algoritma Fisher-Yates Shuffle untuk pengacakan soal pada permainan.Hasil pengujian yang telah dilakukan pada anak-anak sekolah dasar menunjukkan bahwa Aplikasi Pembelajaran yang melibatkan aktivitas motorik dinilai baik oleh anak-anak dengan tingkat kepuasan hingga 80\%. Dengan demikian, Aplikasi ini dapat digunakan sebagai alternatif media pengenalan Bahasa Inggris pada anak-anak dengan permainan yang melibatkan aktivitas motorik.
\end{abstract}

Kata Kunci: Bahasa Inggris, Aplikasi Pembelajaran Bahasa Inggris, Fisher-Yates Shuffle, Kinect

\section{Pendahuluan}

Bahasa Inggris memiliki peranan penting dalam dunia kerja dan pendidikan, karena bahasa inggris merupakan bahasa internasional yang digunakan untuk berinteraksi di dunia global. Pengenalan bahasa inggris kepada anak-anak akan sangat baik apabila dilakukan sejak usia dini karena anak-anak pada usia dini cenderung lebih cepat dalam memahami materi-materi baru. Berdasarkan teori Jean Piaget, pada masa kanak-kanak kemampuan motorik berkembang sejalan dengan perkembangan kemampuan kognitif. Kemampuan motorik merupakan kemampuan fisik atau gerak, sedangkan kemampuan kognitif merupakan kemampuan dalah hal kecerdasan. Salah satu cara yang dapat digunakan adalah dengan memanfaat teknologi multimedia dalam aplikasi pembelajaran. Teknologi multimedia yang semakin berkembang memiliki peran besar dalam dunia ilmu pengetahuan. Munculnya berbagai teknologi baru yang beragam, dapat membantu para murid dan guru dalam proses pembelajaran.

Microsoft mengenalkan teknologi baru perangkat game controller pada tahun 2010. Teknologi ini bernama Microsoft Kinect yang memungkinkan pemain dalam menggunakan gerak tubuh untuk mengendalikan permainan. Para pengembang aplikasi dapat menerapkan teknologi $3 D$ motion capture, facial recognition, dan voice recognition ke dalam berbagai macam jenis permainan dan aplikasi pembelajaran.

Berdasarkan uraian di atas maka penulis ingin membangun sebuah aplikasi pembelajaran bahasa inggris untuk anak-anak yang melibatkan aktivitas motorik dengan menggunakan teknologi Kinect yang diharapkan dapat membantu anak-anak usia dini dalam mempelajari bahasa inggris.

\section{Landasan Teori}

\subsection{Microsoft Kinect}

Microsoft Kinect adalah sebuah aksesori untuk platform Microsoft Xbox 360. Kinect merupakan sebuah motion sensing unit device yang dikembangkan untuk menginterpretasikan gerak tubuh manusia. Device ini memiliki Kamera RGB, depth sensor, dan multi-array microphone. Dengan sensor-sensor tersebut Kinect dapat menyajikan kemampuan melakukan full-body 3D motion capture, facial recognition, dan voice recognition.

\subsection{Pembelajaran Multimedia Interaktif}

Menurut Daryanto (2010), multimedia interaktif adalah suatu multimedia yang dilengkapi dengan alat pengontrol yang dapat dioperasikan oleh pengguna, sehingga pengguna dapat memilih apa yang dikehendaki untuk proses selanjutnya. Berdasarkan pengertian tersebut, multimedia interaktif dapat didefinisikan perpaduan berbagai 
macam kombinasi seperti teks, grafik, suara dan animasi, perpaduan tersebut dilengkapi dengan alat pengontrol yang dapat dioperasikan oleh pengguna.

\subsection{Pentingnya Aktivitas Motorik Anak}

Perkembangan motorik berhubungan dengan perkembangan kemampuan gerak anak. Gerak merupakan unsur utama dalam pengembangan motorik anak. Oleh sebab itu, perkembangan kemampuan motorik anak akan dapat terlihat secara jelas melalui berbagai gerakan dan permainan yang dapat mereka lakukan. Jika anak banyak bergerak maka akan semakin banyak manfaat yang dapat diperoleh anak ketika ia makin terampil menguasai gerakan motoriknya.

\subsection{Pembelajaran Bahasa Inggris Untuk Anak Usia Dini}

Anak-anak usia dini pada umumnya tidak dapat berbicara secara fasih dikarenakan tidak dirancang untuk dibangun rasa kepercayaan diri sehingga mengalami kesulitan untuk berbahasa Inggris secara alami. Pondasi terpenting dalam berbahasa Inggris adalah membaca, menulis, mendengar, berbicara, tata bahasa dan kosakata. Untuk dapat bersaing dengan negara-negara lain, kualitas berbahasa Inggris yang baik dan benar harus terus diupayakan untuk ditingkatkan, terutama di mulai sejak dini.

\subsection{Algoritma Fisher-Yates Shuffle}

Fisher-Yates shuffle (diambil dari nama Ronald Fisher dan Frank Yates) atau juga dikenal dengan nama Knuth shuffle (diambil dari nama Donald Knuth), adalah sebuah algoritma untuk menghasilkan suatu permutasi acak dari suatu himpunan terhingga, dengan kata lain untuk mengacak suatu himpunan tersebut. Jika diimplementasikan dengan benar, maka hasil dari algoritma ini tidak akan berat sebelah, sehingga setiap permutasi memiliki kemungkinan yang sama. Metode dasar yang digunakan untuk menghasilkan suatu permutasi acak untuk angka 1 sampai $\mathrm{N}$ adalah sebagai berikut:

1. Tuliskan angka dari 1 sampai N.

2. Pilih sebuah angka acak K diantara 1 sampai dengan jumlah angka yang belum dicoret.

3. Dihitung dari bawah, coret angka $\mathrm{K}$ yang belum dicoret, dan tuliskan angka tersebut di lain tempat.

4. Ulangi langkah 2 dan langkah 3 sampai semuat angka sudah tercoret.

5. Urutan angka yang dituliskan pada langkah 3 adalah permutasi acak dari angka awal.

Pada versi modern digunakan sekarang, angka yang terpilih tidak dicoret, tetapi posisinya ditukar dengan angka terakhir dari angka yang belum terpilih. Berikut ini adalah contoh pengerjaan dari versi modern. Range adalah jumlah angka yang belum terpilih, roll adalah angka acak yang terpilih, scratch adalah daftar angka yang belum terpilih, dan result adalah hasil permutasi yang akan didapatkan.

Tabel 1. Contoh Pengerjaan Fisher-Yate Shuffle

\begin{tabular}{|c|c|c|l|}
\hline Range & Roll & Scratch & \multicolumn{1}{|c|}{ Result } \\
\hline & & 12345678 & \\
\hline $1-8$ & 6 & 1234587 & 6 \\
\hline $1-7$ & 2 & 173458 & 26 \\
\hline $1-6$ & 6 & 17345 & 826 \\
\hline $1-5$ & 1 & 5734 & 1826 \\
\hline $1-4$ & 3 & 574 & 31826 \\
\hline $1-3$ & 3 & 57 & 431826 \\
\hline $1-2$ & 1 & 7 & 543132 \\
& & & 6 \\
\hline
\end{tabular}

Permutasi yang didapatkan adalah 75431826 .

\section{Metodologi Penelitian}

Metodologi yang digunakan adalah metode pengembangan multimedia Luther-Sutopo yang terdiri dari 6 tahapan:

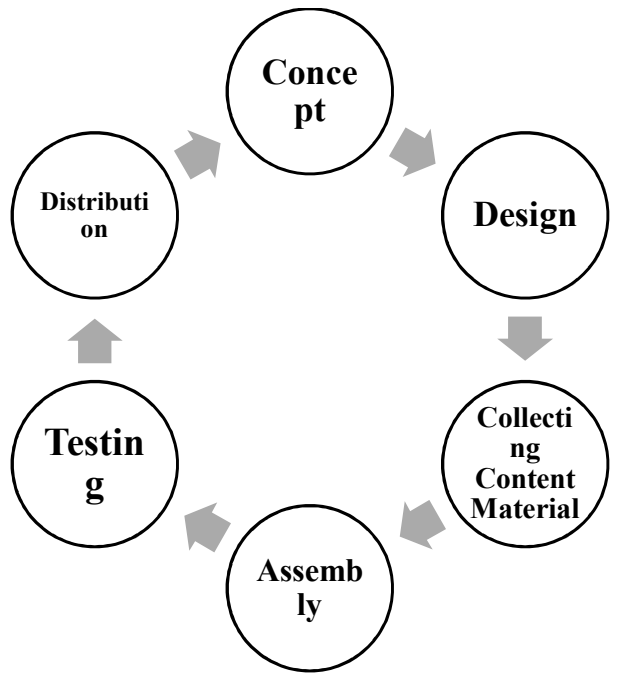

Gambar 1. Diagram Pengembangan Multimedia

\section{Implementasi}

\subsection{Perancangan Menu Let's Practice}

Berisikan latihan dalam bentuk permainan yang beragam. Setiap soal yang ada ditampilkan secara acak dan pada akhir permainan diberikan scoring untuk menilai hasil jawaban dari soal-soal yang telah diberikan.

a. Menu Complete the Words: Terdapat hurufhuruf yang berjatuhan dari atas screen dan User harus menangkap huruf untuk melengkapi kata.

b. Menu Grab the Fruits and Vegetables: Terdapat Magic Tree yang berisi buahbuahan dan sayur-sayuran dan User harus 
memetik buah dan sayur dengan cara melompat.

Berikut ini adalah perancangan kontrol permainan dengan sensor Kinect menggunakan software FAAST (Flexible Action and Articulated Skeleton Toolkit):

a. Right Hand digunakan untuk mengontrol mouse cursor.

b. Left Arm Forward digunakan untuk Click.

c. Lean Left digunakan untuk menggerakkan avatar ke arah kiri.

d. Lean Right digunakan untuk menggerakkan avatar ke arah kanan.

e. Jump digunakan untuk menggerakkan avatar ke arah atas (melompat).

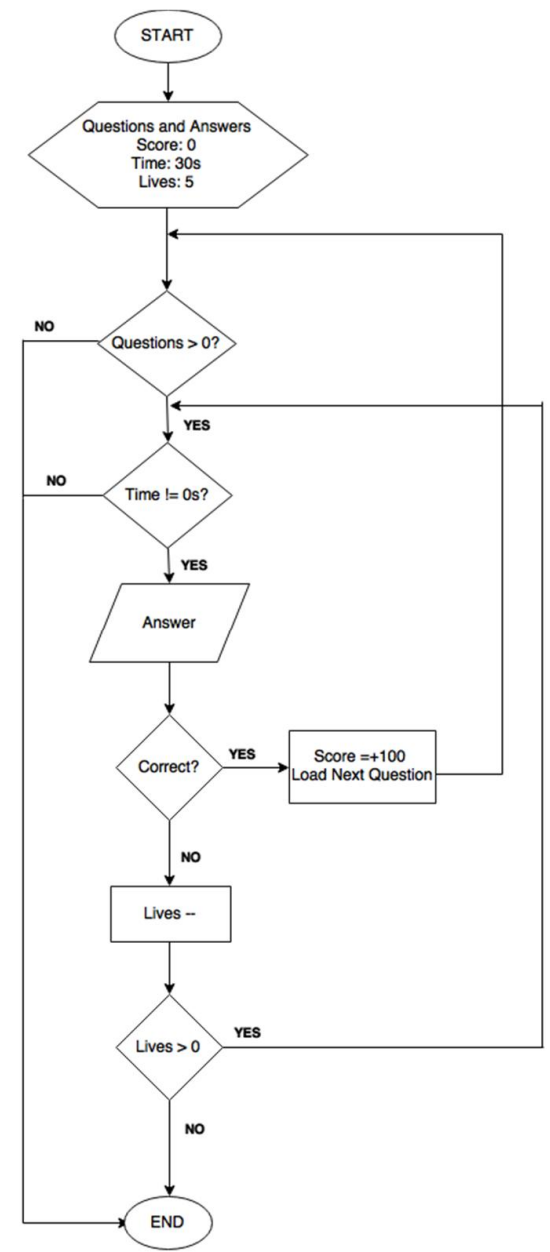

Gambar 2. Flowchart Gameplay

Saat avatar memilih jawaban yang salah, terjadi pengurangan nyawa sebanyak 1 dan saat avatar menjawab dengan benar terjadi penambahan skor sebanyak 100 points. Apabila nyawa telah habis maka game akan dihentikan dan dilakukan penghitungan skor beserta jumlah bintang yang didapat. Apabila nyawa belum habis, maka User masih bisa mencoba untuk menjawab lagi hingga avatar menyentuh huruf yang benar. Saat countdown timer telah habis, maka game akan dihentikan dan dilakukan penghitungan skor beserta jumlah bintang yang didapatkan. Saat pertanyaan sudah habis User berhasil menyelesaikan semua soal dengan benar, maka game akan dihentikan dan dilakukan penghitungan skor beserta jumlah bintang yang didapatkan. Berikut ini adalah Flowchart Algoritma Fisher Yates yang digunakan untuk pengacakan soal:

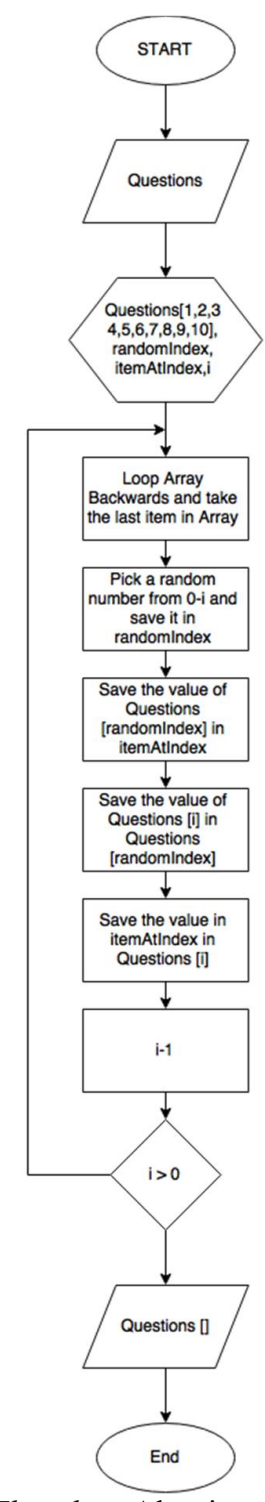

Gambar 3. Flowchart Algoritma Fisher-Yates

\section{Implementasi}

Aplikasi dibangun meggunakan software Adobe Flash CS6 dengan menggunakan Bahasa ActionScript 3.0.

\subsection{Implementasi Gameplay Complete the Words}


Pada awal game dilakukan inisiasi variabel scoreTotal untuk menampung skor dengan skor awal 0 , correctAlphabet untuk jawaban benar, myLives untuk menampung jumlah nyawa dengan jumlah nyawa awal 5 , questions berupa array $[1,2,3,4,5$, dst], dan myTimer untuk countdown timer. Waktu adalah 30s untuk setiap soal. Huruf yang berjatuhan di acak secara random dari Movie Clip Alphabet. Posisi huruf juga diacak secara random.

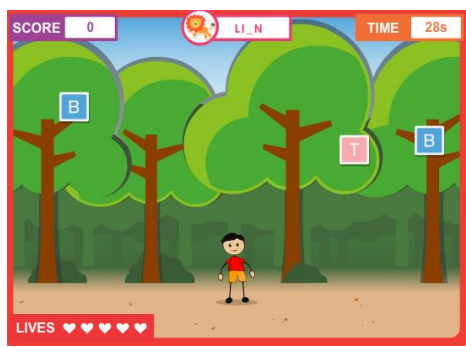

Gambar 4. Gameplay Complete the Words

\subsection{Implementasi Gameplay Grab the Fruits and Vegetables}

Pada awal game dilakukan inisiasi variabel scoreTotal untuk menampung skor dengan skor awal 0 , correctAlphabet untuk jawaban benar, myLives untuk menampung jumlah nyawa dengan jumlah nyawa awal 5 , questions berupa array $[1,2,3,4,5$, dst], dan myTimer untuk countdown timer. Waktu adalah 30s untuk setiap soal. Pada frame selanjutnya dideklarasikan variabel position berupa array $[35,100,180,240,305,370,435,510]$ yang merupakan posisi $\mathrm{x}$ dari buah dan sayuran yang akan ditampilkan.

Penentuan posisi y pada buah dilakukan di dalam Movie Clip fruitsMove.

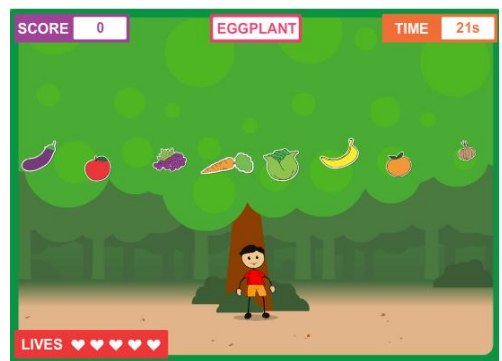

Gambar 5. Gameplay Grab the Fruits and Vegetables

\section{Analisis dan Pengujian}

Pengujian dilakukan melalui dua tahap yaitu pengujian fungsional yaitu pengujian jalannya aplikasi dan pengujian performa yaitu pengujian aplikasi kepada User.

\subsection{Pengujian Fungsional}

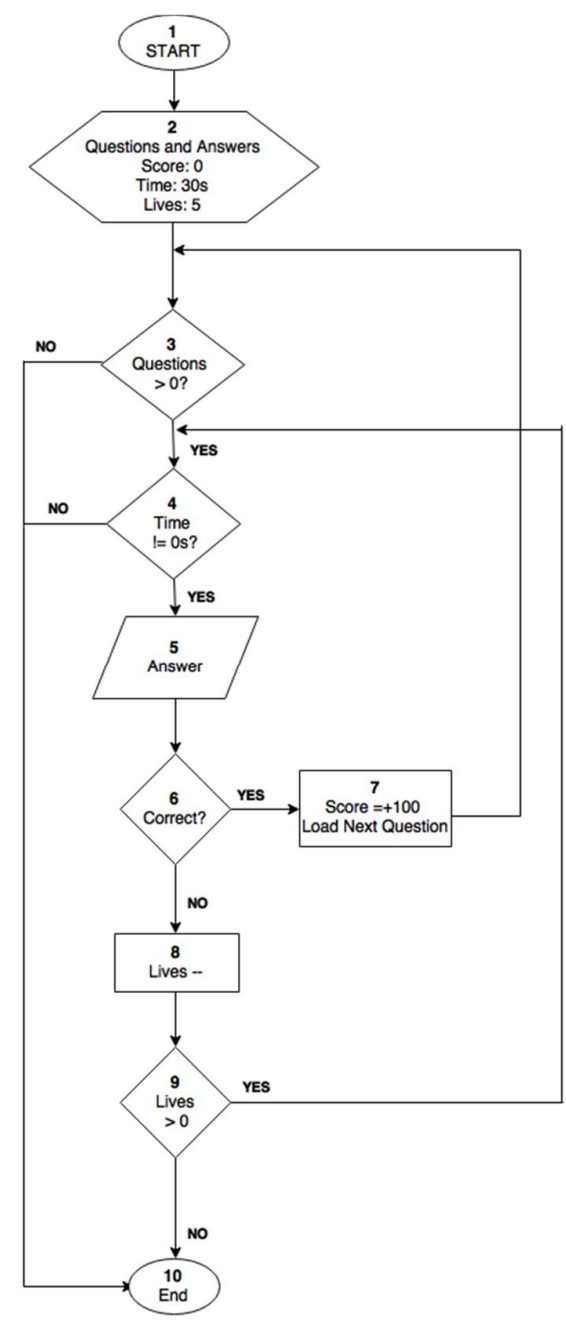

Gambar 6. Flowgraph Gameplay

Pengujian Gameplay dilakukan dengan menggunakan White Box Testing dan dihasilkan 6 path dari Flowgraph:

- $\quad$ Path $1=1-2-3-4-5-6-7-3-10$

- $\quad$ Path $2=1-2-3-4-5-6-7-3-4-10$

- $\quad$ Path $3=1-2-3-4-6-8-9-4-10$

- $\quad$ Path $4=1-2-3-4-6-8-9-4-5-6-7-3-10$

- $\quad$ Path $5=1-2-3-4-6-8-9-4-10$

- $\quad$ Path $6=1-2-3-4-6-8-9-10$

Dari enam Path tersebut dilakukan pengujian dan semua path yang diuji berjalan sesuai dengan harapan. Pengujian Menu menggunakan Black Box Testing dan semua hasil pengujian Menu sesuai dengan hasil yang diharapkan. Berikut ini adalah hasil pengujian Algoritma Fisher-Yates:

Tabel 2. Hasil Pengujian Algoritma Fisher-Yates

\begin{tabular}{|c|c|}
\hline Urutan Array Awal & Urutan Array Akhir \\
\hline Questions $=$ & Questions $=$ \\
{$[1,2,3,4,5,6,7,8,9,10]$} & {$[5,8,4,6,2,1,9,7,10,3]$} \\
\hline
\end{tabular}


Dari hasil pengujian tersebut terbukti bahwa Algoritma Fisher-Yates berhasil diterapkan pada kedua game yang ada. Berikut ini adalah hasil pengujian deteksi Gesture Kinect:

Tabel 3. Hasil Pengujian Right Hand Cursor

\begin{tabular}{|c|c|}
\hline $\begin{array}{c}\text { Tangan yang } \\
\text { Digerakkan }\end{array}$ & Hasil \\
\hline Tangan Kanan & $\begin{array}{c}\text { Mouse Cursor mengikuti } \\
\text { gerakan tangan. }\end{array}$ \\
\hline Tangan Kiri & $\begin{array}{c}\text { Mouse Cursor tidak } \\
\text { mengikuti gerakan tangan. }\end{array}$ \\
\hline
\end{tabular}

Tabel 4. Hasil Pengujian Gesture Left Arm Forward

\begin{tabular}{|c|c|}
\hline $\begin{array}{c}\text { Tangan yang } \\
\text { Digerakkan }\end{array}$ & Hasil \\
\hline Tangan Kiri & Mouse click. \\
\hline Tangan Kanan & Mouse tidak dapat click. \\
\hline
\end{tabular}

Tabel 5. Hasil Pengujian Gesture Foot Sideways

\begin{tabular}{|c|c|}
\hline Arah Gerak Tubuh & Hasil \\
\hline Condong Ke Kiri & Avatar bergeser ke kiri \\
\hline Condong Ke Kanan & Avatar bergeser ke kanan. \\
\hline
\end{tabular}

Tabel 6. Hasil Pengujian Gesture Jump

\begin{tabular}{|c|c|}
\hline Gesture & Hasil \\
\hline Jump & Avatar melompat. \\
\hline Left Arm Forward & Avatar tidak melompat. \\
\hline
\end{tabular}

Dari hasil pengujian tersebut, semua Gesture Kinect berhasil di deteksi sesuai dengan harapan.

\subsection{Pengujian Performa}

Pengujian performa dilakukan dengan memberikan kuisioner pada User setelah User menggunakan aplikasi. User yang diambil adalah anak-anak sekolah dasar yang sedang duduk di kelas 1 dan 2 SD. User terdiri dari 6 orang laki-laki dan 4 orang perempuan. Berikut ini adalah hasil pengujian kuisioner:

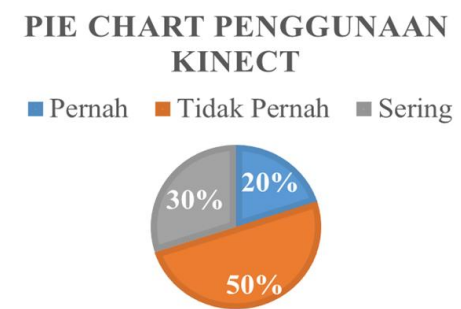

Gambar 7. Pie Chart Penggunaan Kinect

Dari Pie Chart tersebut dapat disimpulkan bahwa sebagian besar dari anak-anak sekolah dasar tersebut belum pernah memainkan game dengan menggunakan sensor Kinect, sebagian diantaranya sudah pernah memainkan game dengan sensor Kinect sebelumnya, dan sebagian diantaranya sering memainkan game dengan sensor Kinect.

\section{Rata-Rata Hasil Penilaian Aplikasi}

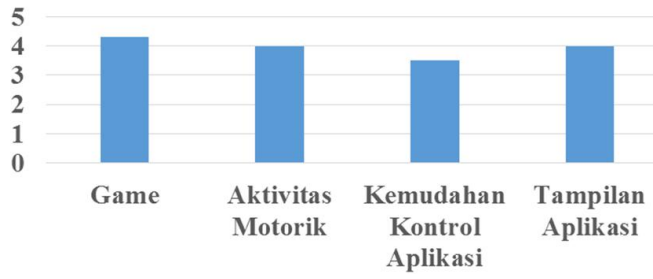

Gambar 8. Grafik Rata-Rata Hasil Penilaian Aplikasi

Dari grafik tersebut dapat dilihat bahwa penambahan game dalam aplikasi pembelajaran memiliki rata-rata nilai 4.3 dengan keterangan baik. Keterlibatan aktivitas motorik pada game memiliki nilai rata-rata nilai 4.1 dengan keterangan baik. Kemudahan dalam penggunaan aplikasi memiliki rata-rata nilai 3.5 dengan keterangan cukup, mendekati baik. Tampilan aplikasi memiliki rata-rata nilai 4 dengan keterangan baik.

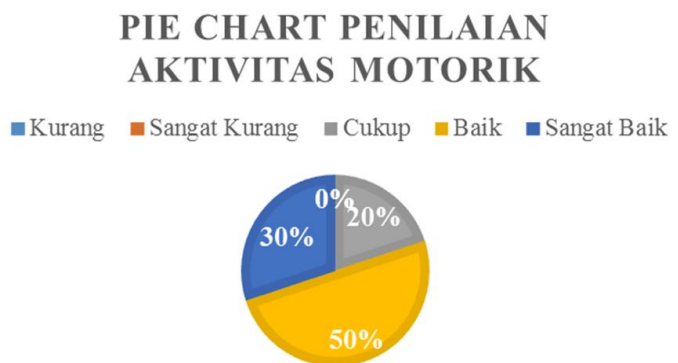

Gambar 9. Pie Chart Penilaian Aktivitas Motorik

Dari 10 sample anak-anak sekolah dasar tersebut, 50\% menjawab Baik dan 30\% menjawab Sangat Baik untuk penilaian keterlibatan aktivitas motorik pada game. Dengan demikian dapat ditarik kesimpulan bahwa tujuan pembuatan aplikasi telah tercapai dan tingkat kepuasan pengguna telah mencapai $80 \%$.

\section{Kesimpulan dan Saran}

\subsection{Kesimpulan}

Dari hasil pengujian aplikasi secara fungsional dan performa yang telah dilakukan, dapat ditarik kesimpulan:

- Aplikasi Pembelajaran Bahasa Inggris yang dilengkapi dengan game dan melibatkan aktivitas motorik dapat digunakan sebagai alternatif media pembelajaran Bahasa Inggris yang dibuktikan dengan hasil pengujian dengan keterangan rata-rata penilaian baik dengan tingkat kepuasan pengguna mencapai $80 \%$.

- Algoritma Fisher-Yates dapat digunakan untuk mengacak soal tanpa terjadi pengulangan soal.

\subsection{Saran}

Berdasarkan penelitian yang telah dilakukan, terdapat beberapa saran untuk pengembangan aplikasi yaitu sebagai berikut: 
- Penambahan fitur multiplayer untuk game.

- Penambahan variasi jenis Gesture untuk gerakan motorik pada game.

\section{Daftar Pustaka:}

Budiman R., Kuswardayan I., Sunaryono D., 2012. Integrasi Kinect dan Unreal Development Kit Menggunakan Kerangka Kerja OpenNI Pada Studi Kasus Game Berbasis Interaksi Gerakan Vol 01, No 1. Surabaya: Institut Teknologi Sepuluh November.

Consultative Group on English Education. 2009. English Hooray! For Elementary School Students Grade 1. Jakarta: Penerbit Erlangga.

Dewi, I., Djatmika, Priyanto, A., 2015.Active English a Fun and Easy English Book for Grade 1 of Elementary School. Solo: PT. Tiga Serangkai Pustaka Mandiri.

Gustiana, Asep Deni. 2011. Pengaruh Permainan Edukasi Terhadap Kemampuan Motorik Kasar dan Kognitif Pada Anak Usia Dini. Jakarta: Universitas Pendidikan Indonesia.

Haryaningtias D. 2013. Pengembangan Multimedia Interaktif Tutorial Materi Gaya, Hukum Newton Dan Pesawat Sederhana Menggunakan Pendekatan Kontekstual. Lampung: Universitas Lampung.

Indrajit, W. 2012. Rancang Bangun Sistem Motion Capture Dan Database Motion Untuk Robot Humanoid Dengan Perangkat Microsoft Kinect
Berbasis Ros (Robot Operating System). Jakarta: Universitas Indonesia.

Khairani, Ade Irma. 2011. Pendidikan Bahasa Inggris Untuk Anak Usia Dini. Medan: Universitas Negeri Medan.

Mutiara, S., Kusuma P., Wibowo S., 2013. Perancangan Dan Simulasi Permainan Penalti Sepakbola Menggunakan Sistem Augmented Reality Pada Kinect. Bandung: Institut Teknologi Telkom.

Runiawati R., Kania C., Sari L., Hendrawan Y., 2013. Perancangan Dan Implementasi Game Bergenre Fighting Berbasis Augmented Reality Menggunakan Motion Sensor Kinect. Jakarta: Universitas Bina Nusantara.

Setyani F., Isnanto R., Martono K., 2013. Pengenalan Bahasa Inggris Untuk Anak Melalui Permainan Edukasi “The Zoo” Berbasis Kinect. Yogyakarta: Universitas Diponegoro.

Susanto, A., Honggo, H. 2013. Perancangan Ujian Online pada STMIK GI MDP Berbasis Web. Palembang: STMIK GI MDP.

Wibowo, A. 2013. Teknologi Natural User Interface Menggunakan Kinect Sebagai Pemicu Kerja Perangkat Keras Berbasis Web. Surabaya: Sekolah Tinggi Ilmu Komputer. 